\title{
Veiling the Mechanical Eye: Antoine Claudet and the Spectacle of Photography in Victorian London \\ Stephen Monteiro
}

In 1851, the French photographic journal La Lumière published a lengthy article under the headline 'Heliography on Metal Plates: A Visit to Mr. Claudet'. In a detailed description of the daguerreotype technique as practiced by Antoine François Jean Claudet, London correspondent F. A. de La Rivière hailed the professional longevity of this French-born portrait photographer and inventor who had immigrated to Britain in 1827. Claudet had just opened his third and final studio, at the height of his career, on Regent Street in the British capital. 'Throughout the twelve years that he's made his art the occupation of his days and nights,' La Rivière exulted, '[Claudet] has maintained all the fervour of the first day'. ${ }^{2}$

If this celebrated photography pioneer, who had begun his career as a glass merchant, still maintained the 'fervour' of exploits stretching back nearly to the 1839 announcement of the medium's invention, his success had lain in converting sheer enthusiasm into a sophisticated promotion of photography itself. In particular, the evolution of Claudet's studios in the first two decades of commercial

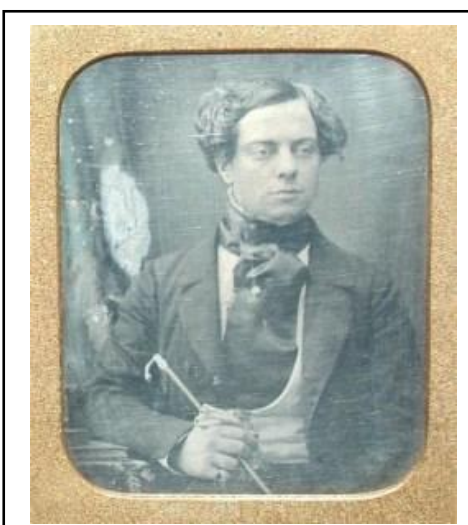

Fig. 1, Antoine Claudet, portrait of an unidentified man, c. 1845, daguerreotype, $78 \times 66 \mathrm{~mm}$. photography saw an increasing effort to veil the technological and scientific apparatus of photography in a spectacle of creativity and luxury. ${ }^{3}$ Although Claudet continued his scientific experiments, culminating in his election to the Royal Society in 1853, as his business grew from a simple rooftop laboratory to a multi-floor showroom, he embedded his means of production deeper and deeper within a competing visual discourse based on studio design and emphasising social refinement and aesthetic beauty. His efforts shifted attention away from the paradoxical understandings of photography as either a natural phenomenon or a method of manufacturing, to present the medium instead as a creative act entrenched in artistic tradition. This strategy especially targeted the upper echelons of British society, which formed the first clientele for the relatively expensive daguerreotype process consisting of a unique image on a silver-coated copper plate (see fig. 1). ${ }^{4}$ 
Through his frequent advertising, surviving correspondence and numerous publications, Claudet's professional trajectory is perhaps the best documented among the handful of photographers working in London before the boom in reproducible, paper-based carte-de-visite portraiture in the early $1860 \mathrm{~s}$. His progression of studios through the city's competing entertainment and commercial spheres linked his business to three well-known London attractions - the Adelaide Gallery on the Strand, the Colosseum at Regent's Park and the Quadrant of Regent Street - each of which represented a different stage in positioning photography within societal discourse by balancing spectacle, commodification and the aura of the art object. After initially embracing the emphasis on the spectacle of technology found in the Adelaide Gallery's scientific lectures and demonstrations, for example, Claudet opened his second studio in 1847 amid the atmosphere of aesthetic illusionism found at the Colosseum, home to Edmund Thomas Parris's celebrated panorama of the city. In 1851, Claudet abandoned both addresses to consolidate his business in a specially-designed, multi-floor studio and showroom in the luxury shopping hub of lower Regent Street, where he remained until his death in 1867.

From nuanced advertising and product packaging to high-profile locations and elaborate interior decoration, Claudet's tactics commingled contemporary trends in artistic practice, popular entertainment and high-end retailing for manufactured goods. Ironically, in consistently maintaining close contact with London sites of technological entertainment, his studios inscribed the photograph more profoundly within the wider culture of the machine precisely to deflect the client's attention from photography's own mechanics. His navigation of London's competing spectacles - scientific, aesthetic and consumerist - and his ultimate professional success underscore the difficulties and rewards of balancing art and technology in the increasingly consumer-driven urban societies of mid-nineteenth-century Europe.

A comparison with the marketing tactics of portrait painting throws Claudet's precarious situation into sharper relief. As Julie Codell stresses in her study of Victorian artistic practices, in the studios of successful portrait painters 'the artist's exertion was displayed in the studio's piles of works, not on the artist's body, making studios sites of the exchange of material, cultural and social capital'. ${ }^{2}$ Like the painter's 'piles of works', from early on Claudet prominently exhibited his

19: Interdisciplinary Studies in the Long Nineteenth Century, 7 (2008) www.19.bbk.ac.uk 
daguerreotype portraits of celebrity sitters - from the Duke of Wellington to French king Louis-Philippe - in his studio's front galleries, and heavily promoted them in his advertisements (see fig. 2). As the daguerreotype is a unique object, these portraits often would be converted into engravings for wider distribution. ${ }^{6}$ Photography's mechanisation also minimised the photographer's exertion more pronouncedly than the painter's, yet the necessary presence of the camera and other equipment risked implying a concomitant reduction in creative human intervention. Indeed, the common designation of photographers at that time as 'operators' reflected and contributed to such a perception.

Because the limits
between artist and
machine were hard to
discern, the relationship
between photographer and
client was more complex

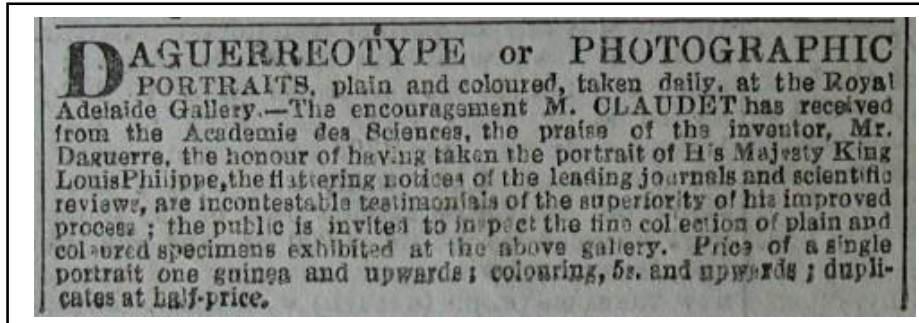

Fig. 2, Advertisement for Antoine Claudet's studio, published in The Times, 3 June 1843, p. 1.

than that of painter and sitter. The photographer's eventual exertion (e.g. buffing, sensitising and developing plates) could be construed as labour servile to the camera apparatus. Claudet's studio presentation eventually minimised the client's awareness both of this labour and of the camera, surrounding them with visual references to the other arts, their practice and their history. In Claudet's business, the act of photography - like that of society painting - became secondary to its attendant spectacle, but here the spectacle grew more and more dependent on paintings, sculpture and architecture to frame not only social relations but the act of imagemaking itself. ${ }^{7}$ Additionally, while painters relocated to the suburbs after midcentury and 'plowed their incomes into fine houses and studios to impress clients, especially upper-class sitters', Claudet and his rivals remained in the retail heart of the city. ${ }^{8}$ If painters sought to distance their products from the trades and wares of the urban marketplace, photographers like Claudet realised the benefits of closely associating their businesses with the rising interest in entertainment, consumer goods and the culture of city shopping. Even while constructing a discourse of exclusivity and aesthetic quality, Claudet seems to have understood the lure of impulse in shopping, as well as the attraction of photography as an exercise in - and 
the concrete product of - social spectacle.

A 'Durable Impression'

Due to English patent restrictions on daguerreotype photography, only one other commercial daguerreotype photographer, Richard Beard, emerged in the British capital to compete with Claudet in the first five years of his business. ${ }^{9}$ Despite this relative lack of competition and the tremendous interest generated by photography's invention, Claudet nevertheless battled early criticisms of the daguerreotype portrait. In particular, many considered its accuracy of detail an insurmountable flaw, given the machine's inability to distinguish the beautiful from the ugly. The daguerreotype was therefore ontologically devoid of the aesthetic potential of painting, as an American journalist for The Knickerbocker pointed out in 1839, even before exposure times had been reduced enough to allow photography's widespread application to portraiture. 'Busts, statues, curtains, pictures, are copied to the very life; and portraits are included, without the possibility of an incorrect likeness,' the journalist explained. 'Indeed, the Daguerreotype will never do for portrait painting. Its pictures are quite too natural, to please any other than very beautiful sitters. It has not the slightest knack at "fancy-work"., 10

In such a critique, the daguerreotype's technological underpinnings disallow the artist's manipulations (or 'fancy-work'), meaning photography might be more useful as a scientific tool than as a method of rendering one's portrait with any amount of aesthetic perspicuity. Claudet's and Beard's initial studio addresses lent credence to this impression. After having exhibited and sold daguerreotype views at his glass shop in High Holborn, Claudet opened his first studio in June 1841 at the Royal Gallery of Practical Science, located at the Lowther Arcade on the Strand and commonly known as the Adelaide Gallery. Only three months earlier, Beard had opened the first commercial photography studio in Britain at the Royal Polytechnic Institute at 309 Regent Street, where Claudet had also exhibited and sold daguerreotypes in $1840 .{ }^{11}$ Both addresses firmly situated the daguerreotype within a technological - rather than an aesthetic - discourse.

Stephen Monteiro, Veiling the Mechanical Eye: Antoine Claudet and the Spectacle of Photography in Victorian London

19: Interdisciplinary Studies in the Long Nineteenth Century, 7 (2008) www.19.bbk.ac.uk 
To fathom the potential ramifications of that discourse, it is worth considering the history and aims of these institutions. Founded in 1832 by the Society for the Illustration and Encouragement of Practical Science, the Adelaide Gallery was a multi-floor attraction equipped with an auditorium, a central exhibition hall and an indoor canal for exhibiting marine-related objects and apparatuses. The Polytechnic, founded in 1838, was similar in its presentation and scope. ${ }^{12}$ Born of the public's fascination with the fruits of the Industrial Revolution, both institutions offered daily demonstrations and lectures on a range of scientific and technological matters, while their galleries contained thousands of inventions, models and artefacts. 'The public display of such productions', explains the Adelaide Gallery's 1838 catalogue, 'must tend to the amusement and instruction of every visitor, and cannot fail to encourage the exertion of individuals [...]'. ${ }^{13}$ The Polytechnic catalogue described its intent to 'demonstrate, by the most simple and interesting methods of illustration, those sound and important principles, upon which every Science is based, and the processes employed in the most useful Arts and Manufactures are conducted'. ${ }^{14}$ In this vein, shortly after the divulgation of the daguerreotype process in 1839, both institutions focused on the invention's technical components by offering public demonstrations that circumscribed the photograph in a discourse of scientific entertainment. ${ }^{15}$ Each institution claimed that its primary mission was instructing the public by illustrating and demonstrating scientific practices; the demonstration of photography presented the photographic process as a performative act reduced to mechanical procedures of optics and chemistry.

The public's eye dominated the attention of these institutions as 'ocular demonstration' strove toward mass spectacle. ${ }^{16}$ 'The education of the eye', the Polytechnic's catalogue contended in 1845, 'is, undeniably, the most important object in elementary instruction'. It added, '[I]nstruction is rapidly and pleasurably communicated [...] leaving behind a valuable and durable impression' with 'important truths being fixed upon the understanding by the ready agency of the

eye'. ${ }^{17}$ Such assertions uncannily described the fundamental actions of photography itself, suggesting the technological spectacle of photography could serve not only in elucidating the medium and attracting audiences but also as an apparently objective demonstration, by scientific means, of the validity of the institution's pedagogical

Stephen Monteiro, Veiling the Mechanical Eye: Antoine Claudet and the Spectacle of Photography in Victorian London

19: Interdisciplinary Studies in the Long Nineteenth Century, 7 (2008) www.19.bbk.ac.uk 
posturing. ${ }^{18}$

While the Adelaide Gallery's fame and popularity (it regularly appeared in guides to the capital) may have offered Claudet early publicity for his studio, its emphasis on technological process and scientific entertainment jeopardised any aesthetic pretensions for the photograph. While Claudet's business soon adopted the elaborately painted backdrops and hand-tinting found in miniature portraiture, in 1841 his studio was just one of the many curiosities at the Adelaide Gallery. Advertising in the Athenaeum a few weeks after opening, the studio announced 'taking portraits and groups of figures at this Institution' by Claudet's 'improved plan' and 'new application', yet the listing included the Adelaide Gallery's other attractions - from the microscope to the steam gun and the electric eel - and concluded with the Adelaide's opening hours and admission prices. ${ }^{19}$ Claudet's Times advertisement later in the month notified readers that '[the Adelaide's] exhibition and amusements are now being augmented, and a variety of new and interesting models will be added to the collection'. ${ }^{20}$ These descriptions presented the daguerreotype studio as little more than an offshoot of the Adelaide's lectures and displays, one technological curiosity among many, accessible only upon paying the Gallery's one-shilling admission. ${ }^{21}$

By 1842, Claudet began to differentiate his business from the rest of the Adelaide Gallery. In February he announced that he had 'completed his new arrangements and [...] fitted up a convenient, comfortable, and elegant room at the [Adelaide] Gallery for taking portraits [...]'.22 Five months later, however, in addition to boasting 'the patronage of Her Majesty and the Nobility', he claimed 'considerable alterations [...] for the convenience and better accommodation of $\mathrm{Mr}$. Claudet's visitors', thus subtly distinguishing his clients from those of the rest of the institution. ${ }^{23}$ When his colleague William Henry Fox Talbot, the inventor of the rival calotype process, wrote him in October concerning a series of photography lectures to be delivered at the Gallery, Claudet responded that 'I have very little contact with the Gallery beyond my photographic transactions, \& [...] I hardly know what happens there'. ${ }^{24}$

Despite his 'new arrangements', Claudet's studio still bore traces of the Adelaide's scientific inclinations, judging from a Times article published in the

19: Interdisciplinary Studies in the Long Nineteenth Century, 7 (2008) www.19.bbk.ac.uk 
summer of 1842. A reporter visiting the studio 'on the summit of the Adelaide Gallery' described it as a simple sitting room beside a 'laboratory'. 'For those who can bear a full light, a seat in the open air on the roof of the gallery is the best situation for a likeness', he explained, 'but [...] a little room with blue glass windows is [also] provided' near 'the laboratory [...] illuminated by red and yellow glass'. 'The plate goes here after the likeness is taken, merely for the purpose of being washed, etc.', the reporter assured. ${ }^{25}$ Despite the article's positive tone, particularly in noting the recent visit of Queen Victoria's mother, the Duchess of Kent (see fig. 3), and Claudet's display of opera portraits, concrete signs of the convenience, comfort and elegance mentioned in the advertisements were meagre at best. In such limited quarters, there was little possibility of

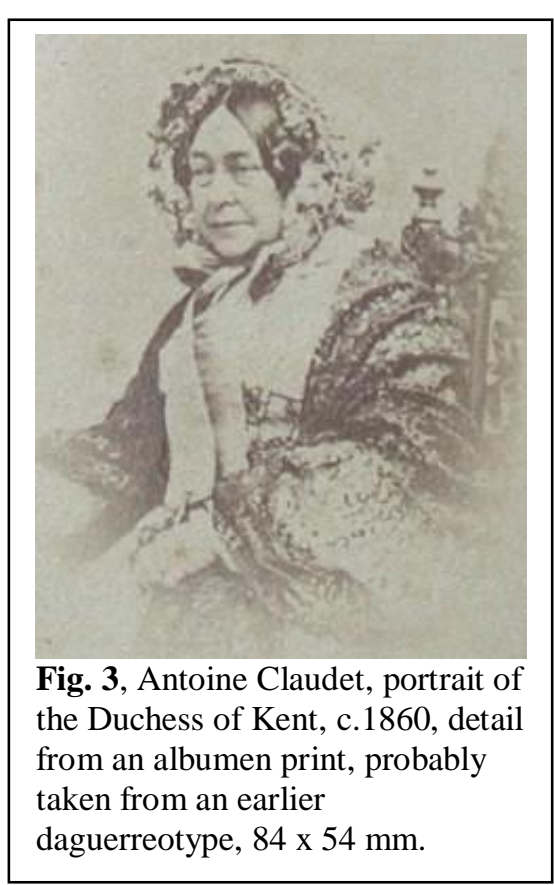
eliminating darkroom activity from the visitors' experience, for instance, let alone shielding them from the scientific gadgetry found in the rest of the building.

Claudet maintained this rooftop studio for a decade, but by 1844 he added waiting rooms (including one exclusively for women) and gave the studio an independent street entrance, around the corner from the Adelaide Gallery's doors, at 18 King William Street (now William IV Street). The new address marked a significant shift in the representation of his business, as an 1844 advertisement made clear: '[V]isitors may now be admitted [...] by a private entrance [...] without, if preferred, passing through the gallery, and consequently free of the usual payment of 1s. for admission'. ${ }^{26}$ Thereafter, Claudet spared his clients the jumble of curiosities and tourists filling the galleries below. Although he could not change the fact that he worked above one of the city's best-known scientific attractions, by 1847 , the year he opened his second studio, Claudet's advertisements regularly omitted mention of the Adelaide Gallery or described it as simply 'near' his rooftop studio. ${ }^{27}$

Stephen Monteiro, Veiling the Mechanical Eye: Antoine Claudet and the Spectacle of Photography in Victorian London

19: Interdisciplinary Studies in the Long Nineteenth Century, 7 (2008) www.19.bbk.ac.uk 
'Invisible Machinery'

As holder of the daguerreotype patent for England, Richard Beard had opened three London studios by 1842 to rival Claudet's Adelaide Gallery business, with premises at 34 Parliament Street in Westminster and 85 King William Street in the City in addition to the Polytechnic studio. Apparently distracted from developing an aggressive marketing strategy for his London studios by his greater goal of selling licences for provincial studios, Beard's strategies developed more slowly than Claudet's. His marketing tactics eventually fell into an alternating pattern of either following Claudet's lead or relying on less-detailed - and often less convincing -

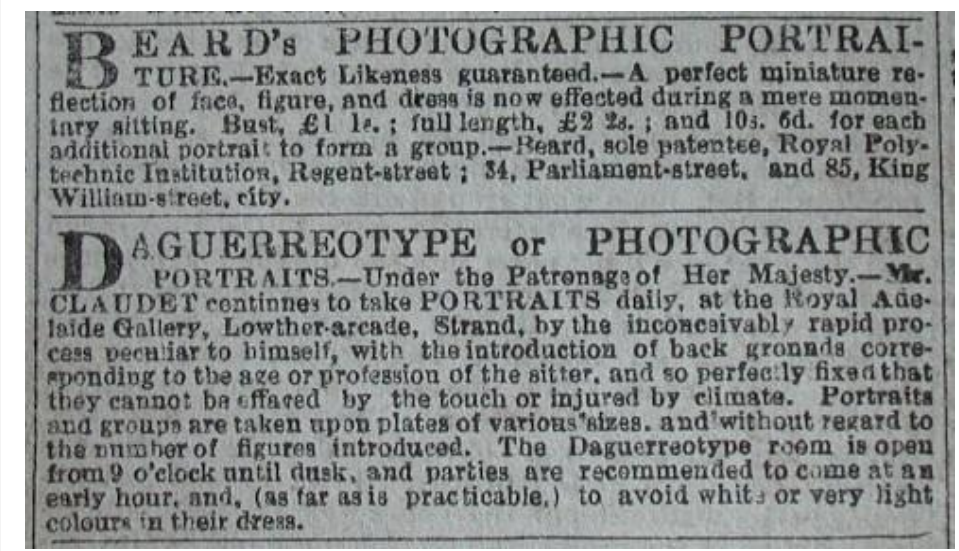

Fig. 4, Advertisements for Antoine Claudet's and Richard Beard's studios, published in The Times, 1 March 1843, p. 1. advertising (see fig. 4). ${ }^{28}$ From the mid1840s, Beard also found his business stymied in legal battles against patent infringements, which eventually contributed to his bankruptcy in 1849. ${ }^{29}$ By 1846, he

had decided to sell licenses for other daguerreotype studios in London, gaining quick income but considerably increasing competition for himself and Claudet. ${ }^{30}$ Among the new arrivals were John Jabez Edwin Mayall and William Edward Kilburn. Mayall, who would make his fortune in carte-de-visite portraiture in the 1860s, had practiced daguerreotypy in the U.S. and opened his 'American Daguerreotype Institution' on the same block as Claudet's studio, at 443 West Strand. Kilburn opened a studio at 234 Regent Street, boasting delicately tinted daguerreotypes and earning the coveted designation of photographer to the Queen by May $1847 .^{31}$

Amidst these developments, Claudet opened a second, more spacious studio

Stephen Monteiro, Veiling the Mechanical Eye: Antoine Claudet and the Spectacle of Photography in Victorian London

19: Interdisciplinary Studies in the Long Nineteenth Century, 7 (2008) www.19.bbk.ac.uk 
on 5 April 1847 in the Colosseum, a leisure attraction on the southeast edge of Regent's Park near the Diorama, the light-and-shadow show owned by the daguerreotype's co-inventor, Louis Jacques Mandé Daguerre. Regent's Park had become the playground of the upper class, where 'the rich, with horse and carriage, ride along the vast lawns', according to French photography critic Francis Wey. ${ }^{32}$ The imposing neo-classical Colosseum opened in 1829 as a gathering place for the well-to-do (see fig. 5). Intended to offer 'the advantages of a club-house in town with the attractions of a rural villa', ${ }^{33}$ it was a moneymaking venture best known for its enormous panorama of the London skyline. ${ }^{34}$ The attendant four acres of manicured gardens recalled the popular Vauxhall Gardens, with rows of tall trees and strategically placed mirrors to block out the city and offer visitors a sense of endless open space. ${ }^{35}$

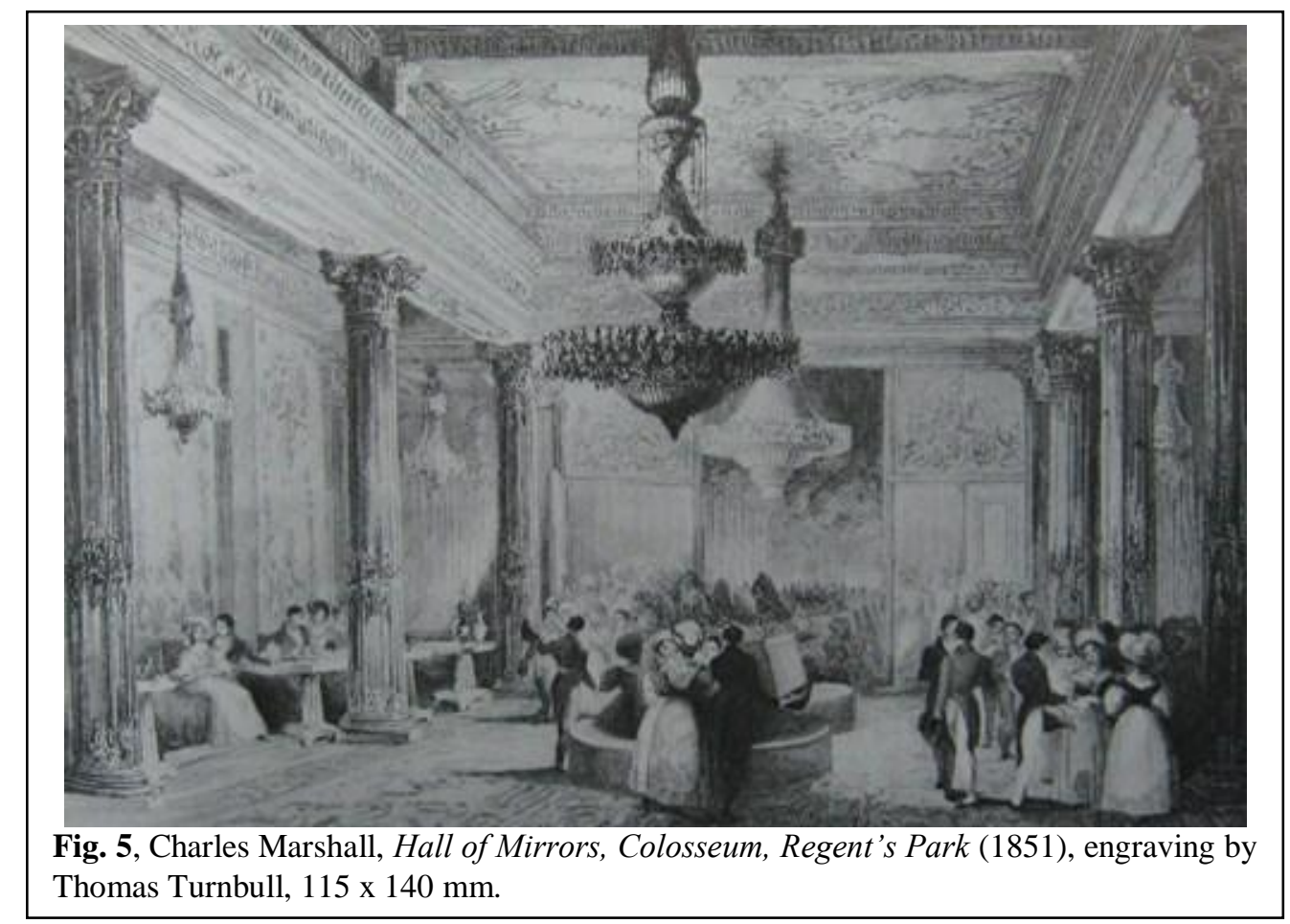

By the time Claudet arrived, the Colosseum had known several owners and fluctuations in popularity. In 1845, however, it had been thoroughly renovated and updated under the supervision of Covent Garden set designer William Bradwell, who conceived such additions as the 'Glyptotheca', or sculpture gallery, and the Cyclorama auditorium. The Glyptotheca, situated in the basement under the panorama, offered 'a lofty dome of several thousand feet of richly-cut glass' with

Stephen Monteiro, Veiling the Mechanical Eye: Antoine Claudet and the Spectacle of Photography in Victorian London

19: Interdisciplinary Studies in the Long Nineteenth Century, 7 (2008) www.19.bbk.ac.uk 
twenty 'fresco paintings of allegorical subjects'. Scattered among the velvet seats and drapery below were works for sale 'from the chisels of some of the most eminent foreign and British sculptors'. ${ }^{36}$ The Cyclorama was similarly decorated, with paintings copying some of the best known classical subjects. ${ }^{37}$ The artificial ruins outside and the ever-popular panorama completed the visit.

The Colosseum's attractions surrounded Claudet's studio with elements meant to engage nineteenth-century ideas of beauty and the sublime through elaborate illusionistic techniques. These necessarily relied on technological advances and mechanical principles but, unlike the Adelaide, the mechanisms were hidden away, allowing only 'the action of invisible machinery' to surface in effects of lighting, sound and movement. ${ }^{38}$ The centre of the experience was the dizzying panorama, which on first impact was meant to 'perplex and confuse the eye and mind'. ${ }^{39}$ One 1838 visitor vividly described how the benefits of new technologies, like the Colosseum's elevator, could transform a visit to the panorama into an unprecedented aesthetic experience involving the entire body. 'The spectator [...] finds himself, by the safe, speedy, and unerring operation of invisible and inaudible mechanism, raised to an elevation whence the whole prospect expands around him', he explained. 'Recovering from the wonder created by this first view of the picture as a whole, [the spectator] finds new cause of astonishment in examining [...] it in detail'. ${ }^{40}$

If the Colosseum made claims to the 'surprising, original, and astonishing' just as the Adelaide Gallery had, it eschewed scientific or even pedagogical emphasis in order to encourage those sensorial immersions that lent themselves to aesthetic contemplation. ${ }^{41}$ It radically transformed the terms of the aesthetic, finding it not only in its contrivances of Nature, but even more potently in the surrounding metropolis. As the Colosseum's 1829 guide declared:

The ocean viewed from the summit of a high cliff - a boundless expanse of country, when seen from the apex of a lofty mountain, are unquestionably objects of grandeur and sublimity; but both are dull and vacant, when compared with the astounding view of London from the top of St. Paul's. This exhibits to the eye and mind, the dwellings of nearly a million and a half of human beings [...] and the manifold pursuits, occupations and powers of its ever-active, ever-changing inhabitants. ${ }^{42}$

In substituting the nearly unfathomable urban sprawl of the British capital for

Stephen Monteiro, Veiling the Mechanical Eye: Antoine Claudet and the Spectacle of Photography in Victorian London

19: Interdisciplinary Studies in the Long Nineteenth Century, 7 (2008) www.19.bbk.ac.uk 
oceans and the countryside, the Colosseum panorama applied the sublime to the modern, technologically-produced landscape. That turn undoubtedly appealed to Claudet who had, in fact, accomplished a similar gesture in 1842 when, commissioned by the Illustrated London News, he produced an acclaimed daguerreotype panorama of London from atop the Duke of York's column in Pall Mall. Published the following year as a $91.5 \times 127$ centimetre ( 36 × 50 inch) composite engraving for subscribers, the magazine's editors touted it as 'a picture bigger than anything previously issued, ${ }^{43}$ Both of these panorama projects implied that the technological and the aesthetic were not mutually exclusive, but could be combined to extraordinary results, so long as technology remained in the background and only its effects were emphasised.

The Colosseum's insinuation of an urban sublime and its successful use of mechanical technology behind spectacle rather than as spectacle perfectly fit Claudet's increasing focus away from photographic processes in promoting his portrait business. For this new address, Claudet emphasised those aspects of the premises that turned the studio visit into a spectacle of leisure. Explicitly addressing 'the nobility and gentry' in his Times advertisement of 1 April 1847, he described the studio as 'fitted up in the most complete and elegant manner' where '[a] wide and easy staircase will lead to spacious rooms at a moderate elevation'. ${ }^{44}$ An advertisement in the Athenaeum the following month stated that 'the rooms [...] are extensive and elegant [and] the nobility and gentry will find the whole establishment in every way most suitable and convenient'. ${ }^{45}$ Even when he advertised that ' $[t]$ he atmosphere of that locality being free from smoke will greatly facilitate the photographic operations', his reference to photography served to suggest more agreeable surroundings and respite from the city's air pollution. ${ }^{46}$

Claudet's Colosseum studio helped deflect attention from the production of the photograph by making the client appear the centre of the spectacle from the moment he or she walked through the door. Whether it was the width of the staircase or the size of the rooms, the setting allowed more opportunity for viewing and being viewed while creating a sentient experience, from the easy climb to the clean air. 'The whole has been calculated for the greatest convenience of visitors', his advertisements insisted, placing emphasis on the client - and the client's body -

Stephen Monteiro, Veiling the Mechanical Eye: Antoine Claudet and the Spectacle of Photography in Victorian London

19: Interdisciplinary Studies in the Long Nineteenth Century, 7 (2008) www.19.bbk.ac.uk 
rather than production, much in the way that society painters had at that time. ${ }^{47}$

The specific details of Claudet's Colosseum advertising - reaching beyond the more general terms of 'convenient', 'comfortable' and 'elegant' that he employed to promote his Adelaide Gallery address - suggested this studio was a considerable improvement. His mention of the suitability of the 'whole establishment' could have implied the Colosseum itself, in contrast to the distancing rhetoric he employed toward the Adelaide Gallery. Yet the Colosseum studio proved to be a short-lived solution, operating for only four years. Among its possible drawbacks, the Colosseum charged admission like the Adelaide. Although Claudet stressed in his advertisements that there was no charge to access his studio ('Admission Free [...] through the front portico'), any admission fee still identified the location as an entertainment enterprise, in contrast to free institutions for aesthetic edification like the National Gallery. As Dianne Sachko Macleod has observed of the Victorian art scene, 'paradoxically, the artist's studio professed to provide a refuge from materialism and commercialism, yet it was structured to induce spending, ${ }^{48}$ If Claudet followed that model, the Colosseum's admission fees threatened his delicately balanced illusion of aesthetic spectacle for a commercial portrait business. As he wrote Talbot in 1844, 'I make a living from the art which I

produce, but I want the public to buy from me without being importuned or harassed as so often happens in a shop'. ${ }^{49}$

The decentralised location was another potential liability. While London's rich relaxed in Regent's Park, they made their purchases elsewhere, particularly Regent Street. If the Colosseum provided more aesthetic credibility, the luxury shopping of Regent Street represented a market for the object available nowhere else, as ideas of beauty and value became more and more applicable to massproduced goods. Even if Claudet rejected typical shopkeeper selling tactics, a carefully appointed studio among the shops of Regent Street could give the illusion of a respite from commercialism, offering a sumptuous salon built on the premise of aesthetic pleasure.

19: Interdisciplinary Studies in the Long Nineteenth Century, 7 (2008) www.19.bbk.ac.uk 
III

'A True Art'

In June 1851 - the year of La Rivière's flattering remarks in La Lumière - Claudet abandoned both the Colosseum and the Adelaide Gallery and consolidated his business at 107 Regent Street, opening a grandiose, custom-designed exhibition hall and studio he christened the 'Temple of Photography'. During construction, Claudet explained 'I will try to organise it, in every detail, based on the lessons of my long experience'. ${ }^{50}$ The Regent Street studio represented the final phase in his effort to combine a spectacle of luxury with the photograph as aesthetic object of artistic pretensions, despite its role as a consumer product.

The introduction of gas lighting, the establishment of reliable train lines and the increased production and quality of manufactured goods had turned London shopping into an important leisure activity by mid-century, even among the highest classes. Designed as a residential street by John Nash and completed in 1823, Regent Street offered large street-front premises that gradually lured growing businesses away from Fleet Street and the City. ${ }^{51}$ In Twice Around the Clock, or the Hours of the Day and Night in London (1859), George Augustus Sala called Regent Street 'one glorious thoroughfare' with 'the unique and almost indescribable cachet which the presence of English aristocracy lends to every place it chooses for its frequentation'. ${ }^{52}$ Sala provided a colourful account of the area as it was during Claudet's time:

Not without reason do I declare it the most fashionable street in the world. I call it not so for the aristocratic mansions it might possess; for the lower parts of the houses are occupied as shops [... and] the shops themselves are innately fashionable. [...] Indeed, Regent Street is an avenue of superfluities - a great trunk-road in Vanity Fair. ${ }^{53}$

Several other photographers - including Beard and Kilburn - were already on upper Regent Street, but Claudet located his studio at the Quadrant of lower Regent Street (see fig. 6). By 1851, that area had become the most fashionable shopping district in the British capital, mixing an abundance of goods with an equal amount of spectacle. 'The shops [...] are most magnificent, full of every thing, and full of

19: Interdisciplinary Studies in the Long Nineteenth Century, 7 (2008) www.19.bbk.ac.uk 
nothing', marvelled American expatriate Henry Colman in $1845 .^{54}$

Claudet's 'Temple', as its name suggested, was to be part spectacle and part mythology, participating in the splendour of the neighbourhood as a platform for pageantry, exaltation and not a little idolatry. 'It's a veritable Pantheon of photography', exclaimed La Lumière's editor-in-chief, Ernest Lacan in 1855. 'It's

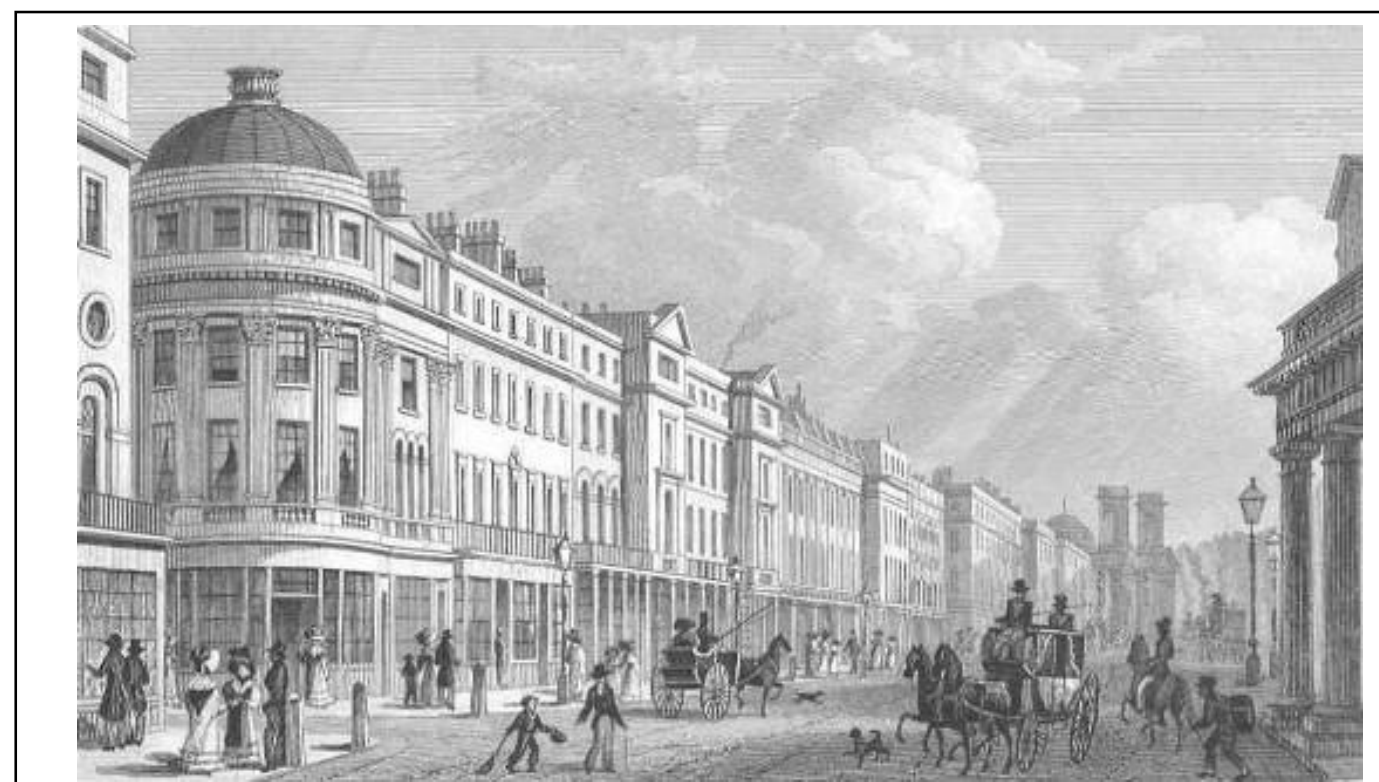

Fig. 6, Thomas Hosmer Shepard, Regent Street from the Quadrant (1828), engraving by W. Tombleson, 140 x $203 \mathrm{~mm}$.

also a beautiful book written in stone: the history of this great discovery' ${ }^{55}$ Two storeys of Italianate waiting rooms, galleries and studios housed allegorical paintings representing branches of the fine arts beside others depicting the invention and expansion of photography, thereby tracing a visual genealogy marrying photography's technological and manufacturing bases to a narrative of artistic precedence and aesthetic creativity.

'[T]he idea is as noble as its execution is admirable', read an 1854 article written upon completion of the studio's decorations and reprinted in La Lumière from an unnamed London French-language newspaper. 'The idea is to represent the various stages through which science had to pass before arriving at the marvellous results produced by photography, and thus to recall the high origins of this art and the respect to which it is entitled'. ${ }^{56}$ Paintings by Hervieu covered the walls of the ground floor showroom. Medallion portraits and arabesques formed a frieze around this rectangular gallery, depicting philosophers, artists and inventors, from Giovanni Battista della Porta and Leonardo Da Vinci to Daguerre and his partner, Nicéphore

Stephen Monteiro, Veiling the Mechanical Eye: Antoine Claudet and the Spectacle of Photography in Victorian London

19: Interdisciplinary Studies in the Long Nineteenth Century, 7 (2008) www.19.bbk.ac.uk 
Niépce. Additional medallions represented the 'four great centres of civilisation' in Athens, Rome, Paris and London. ${ }^{57}$

Upon entering from the street, the gallery's right wall bore a mural of the French Chamber of Deputies, which had voted in 1839 to compensate Daguerre and Niépce's heirs for the daguerreotype process. The left wall bore a view of the Great Exhibition of 1851 and of Somerset House on the river Thames, home to the Royal Society, where Talbot's photographic process was first announced. Beyond these historical references, the arcaded wall facing the entrance framed a five-panel series representing sculpture, painting, photography's invention, portrait photography and stereo photography (which Claudet began offering by October 1851 as an important component of his production). ${ }^{58}$ This suite of images confronted the visitor with a mythology binding photography - particularly in its principle commercial applications - and the fine arts. ${ }^{59}$

An adjacent stairway leading to the 'large, improved, and well-ventilated Crystal Building' that served as the portrait studio included paintings glorifying paper-, glass- and metal-based photographic processes. ${ }^{60}$ 'In this same room, of which the walls are hereafter sacred thanks to these artistic gems', the 1854 article explained, 'Mr. Claudet exhibits charming photographic proofs'. Faced with this wealth of visual narrative, the anonymous writer (who may have been Claudet himself) reached the conclusion that 'upon leaving Mr. Claudet's showroom, one remains under the influence of this idea: photography is a true art [...]'.61

In the landmark essay 'The Metropolis and Mental Life' (1903), Georg Simmel observed that ' $[\mathrm{t}]$ he modern city [...] is supplied almost exclusively by production for the market, that is, for entirely unknown purchasers who never appear in the actual field of vision of the producers themselves'. ${ }^{62}$ While the photographic portrait was one among innumerable products available for purchase in the shops of Regent Street in the mid-nineteenth century, it was a rarity in requiring close contact not only between purchaser and producer, but between purchaser and the means of production. The spatial organisation of Claudet's Regent Street studio, however, along with its extensive visual citations (in material, style and content) of artistic practice incorporating photographic production, deflected attention from the immediate technological means of that production. Accordingly, exposure to the

Stephen Monteiro, Veiling the Mechanical Eye: Antoine Claudet and the Spectacle of Photography in Victorian London

19: Interdisciplinary Studies in the Long Nineteenth Century, 7 (2008) www.19.bbk.ac.uk 
necessary mechanical and chemical processes was reduced to a minimum.

On his 1855 visit to the studio, Lacan marvelled at the virtual elimination of camera operations, and even the camera itself, from the client's perception. '[The] camera is placed under a type of square, portable tent, that has only a relatively small opening on the side facing the sitter,' Lacan explained, 'such that the camera obscura is completely protected from outside rays [of light]'. Not only did this tent eliminate unwanted light from infiltrating the camera body, according to Lacan, but 'in addition, the person posing isn't distracted by the operator's movements, which is also worth considering, ${ }^{63}$ In this environment, the photographer could mimic the society painter. Image production became a social visit, steeped in ideas of pleasure and beauty while seemingly detached from labour and commerce.

Claudet also situated his darkrooms at the remote edge of the building, enclosing processing equipment in shuttered cabinets with slots for manipulating the plates during development and fixing. ${ }^{64}$ These modifications were primarily safety measures, yet they also demonstrate to what extent those operations that were once highlighted as the essential rituals of photography in the lecture rooms of the Adelaide Gallery (or gleaned from a visit to the small rooftop studio there) were hereafter thoroughly expunged from the public's experience. The client's arrival in front of the concealed camera was the final step of a visual progression that so thoroughly intertwined photography and painting as to suggest they were one and the same. Understanding photography now meant situating it within wider traditions of image-making rather than appreciating the specificity of its production. The heavy reliance on concealment and illusion, drawn in part from Claudet's Colosseum stay and far removed from the Adelaide Gallery's efforts to lay technology bare, suggests Claudet understood that the process of spectacle, rather than the spectacle of process, was critical to the photographic portrait's viability as an aesthetic object.

By these actions, Claudet not only strove to situate the photograph within a wider artistic tradition, but to evoke nothing short of an aura for the photographic object. ${ }^{65}$ He replaced any understanding of mechanical process with a revisionist narrative of artistic ritual embedded within the fine arts while nonetheless appealing to rising commodity desires. In overlapping the photographic object and the client's

Stephen Monteiro, Veiling the Mechanical Eye: Antoine Claudet and the Spectacle of Photography in Victorian London

19: Interdisciplinary Studies in the Long Nineteenth Century, 7 (2008) www.19.bbk.ac.uk 
body at the centre of a spectacle of luxury that began with the window displays of Regent Street and continued into the studio's upper rooms, Claudet's tactics reveal an understanding that the desirability of the object could be enhanced by underplaying its mechanical aspects and reducing awareness of the machine at the centre of the event. Passing from the daguerreotype to paper print formats as they became the norm in the late-1850s, Claudet's Regent Street studio had supplanted the awkward public positioning of photography as technological process with the perhaps more precarious placement of the photograph as somewhere between art and commodity. Its principal process was now social, multiplying the object's uses and meanings in the cultural sphere. The photograph no longer simply denoted the photographic process, but became an object with complex connotations in societal discourse, as one spectacle effectively replaced another.

\section{List of Figures}

Fig. 1, Antoine Claudet, portrait of an unidentified man, c. 1845, daguerreotype, 78 x $66 \mathrm{~mm}$.

Fig. 2, Advertisement for Antoine Claudet's studio, published in The Times, 3 June 1843 , p. 1.

Fig. 3, Antoine Claudet, portrait of the Duchess of Kent, c. 1860, detail from an albumen print, probably taken from an earlier daguerreotype, 84 x $54 \mathrm{~mm}$.

Fig. 4, Advertisements for Antoine Claudet's and Richard Beard's studios, published in The Times, 1 March 1843, p. 1.

Fig. 5, Charles Marshall, Hall of Mirrors, Colosseum, Regent's Park (1851), engraving by Thomas Turnbull, 115 x $140 \mathrm{~mm}$.

Fig. 6, Thomas Hosmer Shepard, Regent Street from the Quadrant (1828), engraving by W. Tombleson, 140 x $203 \mathrm{~mm}$.

19: Interdisciplinary Studies in the Long Nineteenth Century, 7 (2008) www.19.bbk.ac.uk 


\section{Endnotes:}

${ }^{1}$ F. A. de La Rivière, 'Héliographie sur plaques métalliques: une visite à M. Claudet', La Lumière, 24 August 1851, pp. 113-14.

2 '[D]epuis douze ans qu'il fait de son art l'occupation de ses jours et de ses nuits, [il] a conservé toute la ferveur du premier jour.' My translation. La Rivière, 'Héliographie sur plaques métalliques', p. 113.

${ }^{3}$ For a consideration of the aesthetics of Claudet's photographs, see Linda Vance Sevey, 'The Question of Style in Daguerreotype and Calotype Portraits by Antoine Claudet' (unpublished master's thesis, Rochester Institute of Technology, 1977).

${ }^{4}$ In 1842 , Claudet charged a guinea (21 shillings) for a simple daguerreotype portrait fitted in a case. See The Times, 16 February 1842, p. 9. A coal miner's average weekly wage at the time was 20 25 shillings, while a weaver usually earned no more than 15 shillings.

5 Julie F. Codell, The Victorian Artist: Artists' Lifewritings in Britain, ca. 1870-1910 (Cambridge: Cambridge University Press, 2003), p. 62.

${ }^{6}$ In an indication of the problematic relationship between photography and painting, The Times reported in 1845 that an engraving by Ryall of the Duke of Wellington was based on Claudet's daguerreotype and a painting made from the daguerreotype by an artist named Solomon. 'The result of the mechanical process was [...] placed in the hands of Mr. Solomon, an artist of rising reputation', it explained, adding that 'The engraving has been principally made from the daguerreotype portrait, the work of Mr. Solomon being used to correct those defects which of necessity arise in all daguerreotype portraits'. The Times, 22 May 1845, p. 7.

${ }^{7}$ Claudet's strategy stands as an early example of the modern, image-based social discourse outlined by Guy Debord a century later. As Debord describes it, 'The spectacle is not a collection of images, but a social relation among people, mediated by images'. Claudet's business model nurtured that situation. See Guy Debord, The Society of the Spectacle, trans. by Donald Nicholson-Smith (New York: Zone Books, 1995), p. 12.

${ }^{8}$ Codell, p. 49.

${ }^{9}$ For assessments of the rivalry between Beard and Claudet, see Roy Flukinger, 'Beard and Claudet, A Further Inquiry', in The Daguerreotype, A Sesquicentennial Celebration, ed. by John Wood (London: Duckworth, 1989), pp. 91-96 and Helmut Gernsheim, The Origins of Photography (New York: Thames and Hudson, 1982), pp. 123-141. For information on Beard's life and career, see Bernard V. and Pauline F. Heathcote, 'Richard Beard: An Ingenious and Enterprising Patentee', History of Photography, 3:4 (1979), 313-29, and Robert B. Fisher, 'The Beard Photographic Franchise in England: An Overview', The Daguerreian Annual (1992), 73-95.

10 'The Daguerreotype', The Knickerbocker, December 1839, reprinted in Secrets of the Dark Chamber: The Art of the American Daguerreotype, ed. by Merry A. Foresta and John Wood (Washington, D.C.: National Museum of American Art/Smithsonian Institution, 1995), pp. 23032 (pp. 231-32). Original emphasis.

\section{Stephen Monteiro, Veiling the Mechanical Eye: Antoine Claudet and the Spectacle of Photography in Victorian London}

19: Interdisciplinary Studies in the Long Nineteenth Century, 7 (2008) www.19.bbk.ac.uk 
11 The Times, 3 March 1840, p. 3 and 6 June 1840, p. 1.

12 For a thorough account of both institutions, see Richard D. Altick, The Shows of London (Cambridge, MA and London: Belknap/Harvard, 1978), pp. 377-89.

13 Society for the Illustration and Encouragement of Practical Science, Catalogue for 1838 (London: William Clowes and Sons, [n. d.]), p. 5.

14 The Polytechnic Institution, Catalogue for 1840 (London: The Polytechnic Institution, 1840), p. iii.

15 As early as October 1839, the Adelaide Gallery had begun exhibiting daguerreotypes reportedly made by the process's inventor, Louis Jacques Mandé Daguerre. Claudet began exhibiting them in March 1840 at the glass shop he shared with his business partner, George Houghton, at 89 High Holborn. See Athenaeum, 26 October 1839, p. 813 and The Times, 3 March 1840, p. 3.

16 The Royal Polytechnic Institution, Catalogue for 1844 (London: The Royal Polytechnic Institution, 1844), p. 5.

17 The Royal Polytechnic Institution, Catalogue for 1845 (London: The Royal Polytechnic Institution, 1845), pp. 5-6.

18 For a consideration of the evolution of the public scientific lecture in Britain, see Ian Inkster, Scientific Culture and Urbanisation in Industrialising Britain (Aldershot: Ashgate, 1997), pp. 80107. In particular, Inkster notes that 'the 1840's and beyond were years not so conducive to the public lecture as an instrument of science education. Just when the public lecture became available to increasing numbers through large venues and reduced charges [...] their [sic] science content declined and they [sic] became absorbed into general entertainment', (pp. 105-06).

19 Athenaeum, 14 August 1841, p. 620.

20 The Times, 31 August 1841, p. 1.

21 Beard's situation at the Polytechnic may have been slightly different. In the same issue of The Times, his studio advertisement appears immediately below a Polytechnic listing that enumerates several new attractions, including daguerreotype lectures with 'a full explanation of the chymical process adopted', and announces a one-shilling admission charge. Beard's advertisement, on the other hand, makes no mention of such charges.

22 The Times, 16 February 1842, p. 9.

23 Athenaeum, 2 July 1842, p. 577 and 23 July 1842, p. 649.

24 '[...J]'ai fort peu de rapports avec la Galerie au delà de mes opérations photographiques \& [...] je sais à peine ce qui s'y passe'. Letter from Antoine Claudet to William Henry Fox Talbot, 7 October 1842, Bradford, National Media Museum, MS 1937-4910 <http://foxtalbot.dmu.ac.uk/letters/transcriptName.php?bcode=ClauA\&pageNumber=5\&pageTotal=44\&referringPage=0> [accessed 10 May 2008].

25 The Times, 19 July 1842, p. 6.

26 The Times, 21 March 1844, p. 1.

27 The Times, 1 April 1847, p. 1.

\section{Stephen Monteiro, Veiling the Mechanical Eye: Antoine Claudet and the Spectacle of} Photography in Victorian London

19: Interdisciplinary Studies in the Long Nineteenth Century, 7 (2008) www.19.bbk.ac.uk 
${ }^{28}$ For example, Claudet began offering hand-tinted daguerreotypes in his 9 April 1842 Times advertisement. See The Times, 9 April 1842, p. 1. Beard, however, did not announce the availability of tinting at his studios until 20 April. See The Times, 20 April 1842, p. 1.

${ }^{29}$ Claudet had purchased a license to practice daguerreotypy before Beard owned the patent. Though Beard fought a legal battle to have that licence rescinded, he ultimately lost.

30 Gernsheim, pp. 137-41.

31 Athenaeum, 29 May 1847, p. 561.

32 'Les gens riches, possédant équipage, arpentent les vastes pelouses'. My translation. Francis Wey, Les Anglais chez eux (Paris: Michel Lévy frères, 1856), p. 160.

33 The Times, 13 December 1828, quoted in Altick, p. 142.

34 Gernsheim, p. 137 and The Times, 1 April 1847, p. 1.

35 Altick, p. 147.

36 The Illustrated London News, 26 April 1845, p. 264.

37 Altick, pp. 155 and 158.

38 'The Colosseum', A Brief Account of the Colosseum, in the Regent's Park, London (London: privately printed, 1829), p. 8.

39 The Colosseum, p. 5.

40 John Britton and Augustus Charles Pugin, Illustrations of the Public Buildings of London, 2nd edn., 2 vols. (London: John Weale, 1838), I, pp. 368-69.

41 An attempt in 1839 to add popular science demonstrations - perhaps prompted by the flurry of interest around the invention of photography - did not last more than a season, being too incompatible with the site's other attractions.

42 A Brief Account of the Colosseum, p. 3.

${ }^{43}$ Gernsheim, p. 134.

44 The Times, 1 April 1847, p. 1.

45 Athenaeum, 1 May 1847, p. 449.

46 The Times, 1 April 1847, p. 1.

47 The Times, 1 April 1847, p. 1.

48 Dianne Sachko Macleod, Art and the Victorian Middle Class: Money and the Making of Cultural Identity (Cambridge: Cambridge University Press, 1996), p. 298, cited in Codell, p. 62.

49 'Je fais mon métier de l'art que je pratique mais je veux que le public m'achète sans être sollicité ni tourmenté comme cela a lieu dans une boutique'. Letter from Antoine Claudet to William Henry Fox Talbot, 24 August 1844, Bradford, National Media Museum, MS 1937-4938 <http://foxtalbot.dmu.ac.uk/letters/transcriptName.php?bcode=ClauA\&pageNumber=21\&pageTotal=44\&referringPage=1> [accessed 10 May 2008].

50 ' $[\mathrm{J}] \mathrm{e}$ tâcherai d'organiser en tous points d'une manière conforme aux leçons d'une longue expérience.' My translation. Antoine Claudet, 'Les Dangers résultant de l'emploi du mercure', $L a$ Lumière, 18 May 1851, p. 59.

51 Roy Porter, London: A Social History (London: Hamish Hamilton, 1994), pp. 127-30 and 200.

Stephen Monteiro, Veiling the Mechanical Eye: Antoine Claudet and the Spectacle of Photography in Victorian London

19: Interdisciplinary Studies in the Long Nineteenth Century, 7 (2008) www.19.bbk.ac.uk 
${ }^{52}$ George Augustus Sala, Twice Around the Clock, or the Hours of the Day and Night in London (London: Houlston and Wright, 1859), p. 144.

${ }^{53}$ Sala, pp. 155-57.

${ }^{54}$ Henry Colman, European Life and Manners in Familiar Letters to Friends (Boston: Little \& Brown, 1850), p. 340.

55 'C'est un véritable Panthéon de la photographie ; c'est aussi un beau livre écrit sur la pierre : l'histoire de cette grande découverte'. My translation. Ernest Lacan, 'La Photographie en Angleterre', La Lumière, 23 June 1855, pp. $97-98$ (p. 97).

56 '[L]'idée est aussi noble que l'exécution en est admirable. L'idée, c'est de représenter les phases diverses par lesquelles a dû passer la science avant d'arriver aux magnifiques résultats obtenus par la photographie, et ainsi de rappeler la haute origine de cet art et le respect auquel il a droit'. My translation. 'Galerie photographique de M. Claudet', La Lumière, 22 July 1854, pp. 114-15 (p. 114).

57 'Galerie photographique de M. Claudet', p. 114.

58 The Times, 28 October 1851, p. 4.

59 Though the dimensions of this space are not specified in the article, the ground floor, including the showroom and storage space, measured 15.25 x 6 metres (50 x 20 feet). See The Times, 27 January 1868 , p. 9 .

${ }^{60}$ Athenaeum, 21 June 1851, p. 649.

61 'En partant du salon de M. Claudet, on reste sous l'influence de cette idée : que la photographie est un art véritable [...]'. My translation. 'Galerie photographique de M. Claudet', p. 115.

${ }^{62}$ Georg Simmel, 'The Metropolis and Mental Life' (1903) in The Blackwell City Reader, ed. by Gary Bridge and Sophie Watson (Malden, MA and Oxford: Blackwell, 2002), pp. 11-19 (p. 12).

63 '[L']appareil est disposé sous une espèce de tente carrée, mobile, qui n'a qu'une ouverture peu considérable du côté du modèle ; de telle sorte que la chambre noire est complètement à l'abri des rayons extérieurs [...] en outre, la personne qui pose n'est pas distraite par les mouvements de l'opérateur, ce qui est encore à considérer.' My translation. Lacan, p. 98.

${ }^{64}$ Claudet, p. 59.

${ }^{65}$ It is worth recalling that when Walter Benjamin published his 'A Short History of Photography' in 1931 he attributed an aura to the daguerreotype precisely to the extent that it seemed to escape the terms of mechanical mass production. See Walter Benjamin, 'A Short History of Photography' in Classic Essays on Photography, ed. by Alan Trachtenberg (New Haven, CT: Leete's Island Books, 1980), pp. 199-216 (pp. 200 and 207-08). 